\title{
The relationship between ecological restoration and the ecosystem services concept
}

\author{
$\underline{\text { Sasha Alexander }}^{1}, \underline{\text { James Aronson }}^{2,3}$, Oliver Whalev $^{4}$ and David Lamb ${ }^{5}$
}

\begin{abstract}
Ecological restoration and the mainstreaming of the concept of ecosystem services will be critical if global society is to move toward sustainability. Conference of the Parties 21 (COP21) of the United Nations Framework Convention on Climate Change and COP12 of the Convention on Biological Diversity should help foster support for vastly increased investment in the better management and restoration of natural capital. Large-scale restoration demonstrably improves ecological functioning to sustain both biodiversity and human well-being. However, much progress is needed to improve the effectiveness and cost efficiency of any restoration. The ecosystem services concept provides a framework for identifying the types of restorative interventions needed to target different forms and degrees of degradation, and achieve goals related to both ecosystem health and delivery of services to people. Moreover, it can strengthen the argument for, and planning of, large-scale restoration and conservation of natural capital. We use case studies from four continents to help demonstrate how the interconnection between ecological restoration and the ecosystem services concept is being utilized in land-use planning and enlightened ecosystem management. We offer ways in which this relationship can be better understood and communicated to support the scaling up of restoration activities to the landscape and regional scales across the full spectrum of land uses and ecosystem types.
\end{abstract}

Key Words: climate change; ecosystem services; land degradation; land use; large-scale ecological restoration; restoring natural capital, rural communities, sustainable development

\section{INTRODUCTION}

Over the past 30 years, our ability to manage intact ecosystems sustainably, and to repair the all-too-many damaged and degraded ones, has improved substantially (Holl et al. 2003, Lamb 2011, Suding 2011). However, to go beyond revegetation, revamping of hydrology, or cleaning up of polluted lands and waters and achieve ecological restoration worthy of its name, then much more transdisciplinary work is needed (SER 2004, Falk et al. 2006, Clewell and Aronson 2012). In addition, policy reforms, more investment in research and development, and heightened ecological awareness are needed to further improve the effectiveness of restoration in both ecological and socialecological terms, and to scale up these activities 100 -fold as is now required (Aronson et al. 2007). Without this, public and private funding for ecological restoration and other restorative activities will continue to be limited and short lived. Ultimately, ecological restoration (sensu SER 2004) must be understood as a wise investment with demonstrable economic returns in both monetary and nonmonetary terms. It should also come to be understood that the restoration of natural capital is a call for progressive ecological economics, not a reinforcement of neoclassical economics and business as usual.

International conventions (e.g., CBD 2012), intergovernmental platforms (e.g., IPBES 2013), and policy calls for massive action (e.g., IUCN 2014) show that ecological restoration is now recognized as a global priority for biodiversity conservation, combating desertification and land degradation, and limiting the impacts of anthropogenic climate change (Aronson and Alexander 2013). Behind all this lies the proven potential for proactive activities to repair ecosystem function, reinstate landscape connectivity, enhance environmental and societal resilience, and improve the quality and flow of nature's benefits to humans, i.e., ecosystem services. Today, countries, communities, and some corporations (e.g., in the agribusiness and mining sectors) that voluntarily engage in restoration, or at least reforestation, efforts increasingly reflect the need to sustain healthy ecosystems and landscapes where they operate. Some are gradually adopting more sustainable and environmentally friendly management practices (for example, Whaley et al. 2011; http://www.alcoa.com.au/sustainability), but stronger incentives are needed and perverse subsidies need to be eliminated.

Over the past two decades, the ecosystem services concept has increasingly been taken into consideration in decision-making processes and in international studies, treaties, and conventions (TEEB 2010, Alexander et al. 2011, Díaz et al. 2015). The concept has already had a profound impact on thinking, particularly when linked to the concept of natural capital (Costanza and Daly 1992, MA 2005, de Groot et al. 2010, Guerry et al. 2015). The concept of restoring natural capital (Aronson et al. 2007) is also gaining ground. In a nutshell, this involves maintaining stocks of renewable and cultivated natural capital to facilitate the continuous and sustainable flow of ecosystem services to societies. These services contribute directly to human well-being and are increasingly being quantified, monitored, and evaluated at various spatial and temporal scales. To integrate such paradigm shifts, various experiments are under way in the form of payments, fees, credits, or rewards for the maintenance and delivery of ecosystem services (Palmer and Filoso 2009). Furthermore, greater cooperation between legislators and scientists can lead to advances in the legal frameworks for the execution and evaluation of restoration projects and programs, as shown by the federal state of São Paulo, Brazil (Chaves et al. 2015).

Natural capital supports ecosystem processes that allow ecosystems to function and in turn to provide services and benefits to humans (see Fig. 1). Likewise, the sustainability of service

\footnotetext{
${ }^{1}$ University of Western Australia, ${ }^{2}$ Restoration Ecology Group, Centre d'Ecologie Fonctionnelle et Evolutive (CNRS-UMR 5175), ${ }^{3}$ Center for Conservation and Sustainable Development, Missouri Botanical Garden, ${ }^{4}$ Royal Botanic Gardens, Kew, ${ }^{5}$ School of Agriculture and Food Science, The University of Queensland

Erratum: Affiliations were edited on 12 May 2016.
} 
provision, ecological integrity, and societal resilience is weakened if ecosystem function is impaired, as occurs when natural areas are transformed by human activities without considering landscape-scale dynamics. Ecological restoration aims to reinstate or enhance the flow of services, whereas the ecosystem services concept offers practical tools and approaches that contribute to and drive the conservation and restoration, the financing of these activities, and the required legislation and consensus building to support the sustainable use of natural resources.

Fig. 1. This pyramid shows how human well-being depends ultimately on renewable and cultivated natural capital. Only when this pyramid is respected can ecological and socioeconomic sustainability be achieved. Renewable natural capital refers to well-functioning ecosystems and their living part, i.e., native biodiversity; cultivated natural capital refers to traditional crop varieties and livestock races, as well as traditional agroecological knowledge (MA 2005). The internal pyramid in the figure is intended to convey that increased human well-being has positive benefits that flow back through the system, with increasingly dissipated effects at larger scales. This in theory should allow society to support and participate in the restoration of natural capital and thereby benefit from the full spectrum of enhanced ecosystem services as well as the inherent value of restored ecosystems.

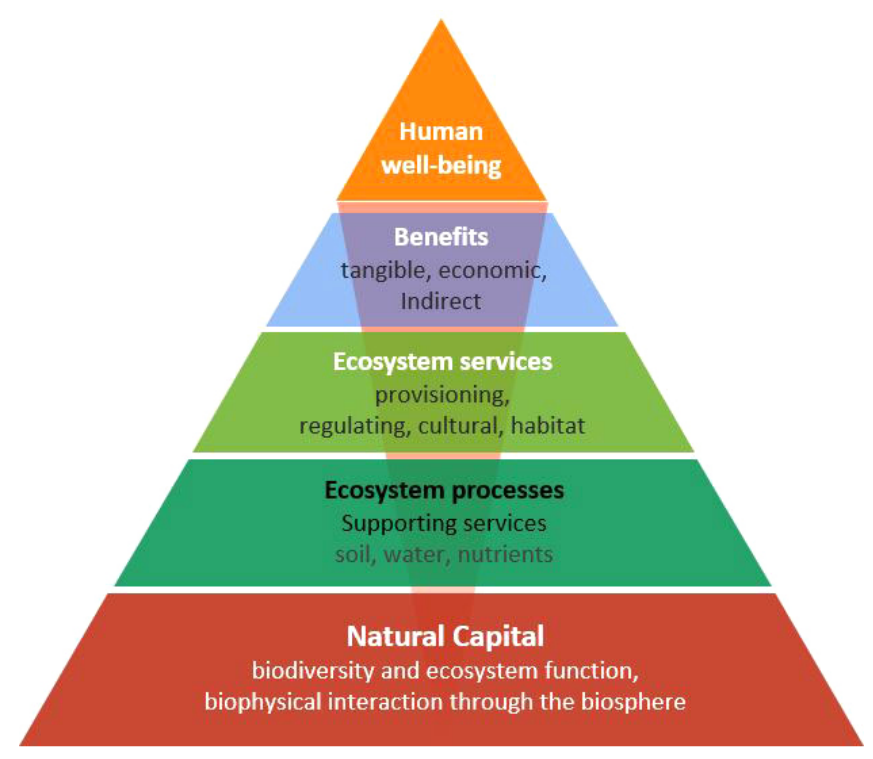

Bullock et al. (2011) noted that restoration projects can be effective in achieving both biodiversity protection and improved flow of ecosystem services, but that conflicts can arise, especially if individual services or benefits are targeted rather than a full spectrum of ecosystem services. Also, although biodiversity is often assumed to be a provider of ecosystem services, it is not proven that increased ecosystem services lead to increased biodiversity, or vice versa (Egoh et al. 2014).

Furthermore, a recent meta-analysis of projects under way in nine different biomes (de Groot et al. 2013) showed that there is a clear economic justification for investing in ecological restoration, particularly in the case of grasslands, woodlands, and forests (cf., Crossman and Bryan 2009). However, in ecological restoration, as in nature conservation, there are many who fear that biodiversity and the inherent values of the "web of life" risk being overlooked or, worse still, commodified if economic valuation alone propels decision making (cf., Worster 1977, Meine et al. 2006, Schröter et al. 2014). Understandable as this concern is, it has to be tempered by the pragmatic need to communicate effectively with private investors and public decision makers; the ecological and economic risks of not finding a common language and therefore failing to engage in restoration, in the context of a rapidly unraveling ecosystem, are surely of far greater cost to society that the perceived risk of commodification of nature.

\section{WHY WORDS MATTER}

Defining ecological degradation in a manner acceptable to all stakeholders has proven to be difficult, but the overall condition of an ecosystem can be assessed in part by quantifying and mapping the diversity and flow of ecosystem services. Indeed the ecosystem services concept has already proven that it can provide common ground for ecologists, environmentalists, and conservationists to engage with economists, policy makers, rural communities, and land-use planners (Naeem 2002, Aronson et al. 2007, TEEB 2010, Neßhöver et al. 2011). Furthermore, provided that definitions and frameworks are clearly understood, this concept, and the related body of science and technology (e.g., spatial analysis and quantification as developed by http://www. es-partnership.org/esp), can help bring together stakeholders with different priorities and values.

Ecological restoration is most commonly defined as "the process of assisting the recovery of ecosystems that have been damaged, degraded, or destroyed" (SER 2004). The recovery envisaged here is the re-establishment of as much as possible of the historical structure, composition, and functioning of the ecosystem that existed prior to degradation. This includes reinstating the evolutionary capacity of the ecosystem to adapt to changing conditions. Thus, restoration is distinct from rehabilitation, where activities focus on functionality and the delivery of targeted services more than on reinstating the predisturbance system condition in all its biological complexity. Rehabilitation may in fact be the only option in situations where degradation has passed a point of no return, where species have become extinct, or where seed and soil biota have all been lost.

When considering restoration versus rehabilitation, the issue of trade-offs inevitably arises with regard to the numbers and identity of species to use, the priorities for ecosystem functions, and the services to be generated by passive or active interventions. The present economic model explicitly favors short-term gains over long-term sustainability. An obvious example is the way in which huge portions of the world's tropical, temperate, and boreal forests have been exploited and removed despite their vital role in sustaining global and local ecosystems alike. This short-term perspective is the opposite management strategy to that of ecological restoration, which aims for a sustainable trajectory of recovery of biodiversity and ecosystem services for the greatest number of beneficiaries for as long as possible-ideally in perpetuity. From both ecological and economic perspectives, as mentioned, rehabilitation is often the most pragmatic response to a condition agreed by all stakeholders as corresponding to 
degradation. Note, however, that in the long-term, rehabilitation can also be undertaken as a first step toward full-scale restoration.

Ecological restoration, by definition (SER 2004), aims to return an ecosystem to a condition or trajectory that existed at some point in the past. Recognizing that this a moving target because of the dynamics of ecosystems and external drivers such as climate change, complete fidelity or $100 \%$ recovery is rarely if ever possible. Thus, Clewell and Aronson (2013) place emphasis instead on recovering historical continuity, that is, attempting to put an impaired ecosystem (i.e., one that is damaged, degraded, or destroyed) on a trajectory in which it can once again evolve and adapt unassisted. The list of nine attributes of a restored ecosystem in the SER primer (2004) provides a matrix against which to consider the classification and effectiveness of diverse projects (cf., Clewell and Aronson 2013), including an expanded and annotated list of attributes. This approach could usefully be developed further to take specific ecosystem services into account.

Having distinguished between rehabilitation and ecological restoration, let us now consider the concept of natural capital. Natural capital is an economic metaphor for the fixed stocks of physical and biological elements found on Earth, some of which are of direct use to society and some of which are not. Natural capital suggests the accumulated wealth of nature, and is a term coined not to "commodify" nature but rather to highlight the fact that in economic terms it is both a renewable and expendable resource just like other forms of capital.

Following Rees (1995), the Millennium Ecosystem Assessment (MA 2005) identified four partially overlapping types of natural capital: (1) renewable, i.e., well-functioning ecosystems and their living part, i.e., native biodiversity; (2) cultivated, defined as traditional crop varieties and livestock races; (3) replenishable, e.g., clean air, potable water, and fertile soils; and (4) nonrenewable, e.g., petroleum, copper, coal, and diamonds. Ecological restoration primarily concerns itself with the first two types.

What then are ecosystem services? As a construct, they flow from natural capital stocks and are transformed by other forms of capital (e.g., human, financial) for the benefit of people. Following the language of the Millennium Ecosystem Assessment (MA 2005), ecosystem services are the array of benefits that society receives from both natural and managed ecosystems. To refine this definition of ecosystem services, it is worth adding that they are "the direct and indirect contributions of ecosystems to human well-being" (de Groot et al. 2010:25), thereby distinguishing between services and benefits by explicitly acknowledging that services can benefit people in both tangible and intangible ways.

Regarding the typology, the Millennium Ecosystem Assessment proposed 22 distinct services (MA 2005; see also de Groot et al. 2010) in 4 main categories: (1) provisioning, e.g., food, fodder, and firewood; (2) regulating, e.g., water regulation, waste recycling, and flood prevention; (3) cultural, e.g., knowledge, recreation, aesthetics; and (4) supporting, e.g., soil formation, nutrient and water cycling, and food chain dynamics.

Although the practice of ecological restoration is quintessentially local and site specific, it is possible to generalize the principles and tools for the planning, implementation, and monitoring of projects in any given ecosystem type (e.g., tropical humid forests, wetlands, rivers, tropical grasslands, or mediterranean-type woodlands and shrublands) by relying in part on the ecosystem services framework. Much depends on the services desired and targeted. Table 1 describes how, in the case of forests, different forms of restoration may be needed to generate particular services. In many degraded landscapes, it can be challenging to restore all of the original species (e.g., because of seed availability, soil degradation, loss of dispersal agents), and difficult choices must be made. However, in most cases, some form of multispecies, or at least genetically diverse, plantings is needed to restore ecosystem function. According to ecological, climatic, and socioeconomic conditions and dynamics, choices can be made concerning the attributes and assemblages of species to generate the desired ecosystem services. It is important to note that some ecosystem services may be generated relatively quickly following restoration (e.g., erosion control, food, and fuel), whereas with others, some time may be needed before benefits accrue (e.g., provision of a clean water supply and suitable habitat conditions for all native species). Some ecosystem services are only likely to be generated when restoration is carried out at the larger landscape scale (i.e., enhanced connectivity and reduced fragmentation) and at strategically important locations rather than at small random sites (Lamb 2014).

\section{GENERATING ECOSYSTEM SERVICES FOR RURAL COMMUNITIES}

Ecosystem functioning is the product of complex interactions among and within species populations, biotic communities, and their abiotic environment, which in turn determine the quantity and quality of ecosystem services that flow to human societies (Mace et al. 2012). In social-ecological systems, it also depends on the actions, and inaction, of local people and the baseline condition of the natural capital with which they are confronted.

Poor communities around the world, especially those in rural areas, are disproportionately dependent on both renewable and cultivated natural capital for their basic needs and survival (World Bank 2010) and are more vulnerable to degradation than urban populations. At the same time, it should be noted that rural agricultural communities provide for urban populations and are often directly linked with flow of ecosystem services. As such, these communities can to be considered as idiosyncratic to ecosystems, even if driven by urban demand. Another key consideration is that the livelihoods of sedentary rural communities depend on a seasonal return from a narrow range of species with low genetic variation over a small area, whereas urban populations, at least while fossil fuel availability continues, are able to ensure supply, albeit unsustainably from sources around the globe.

Given the range of spatial and temporal scales associated with ecosystem services, trade-offs and negotiations are necessary and inevitable. For example, regulating and supporting services are more apparent at larger scales and affect larger pools of stakeholders than cultural or provisioning services. The flow of some services generated by activities in more distant parts of the landscape can result in an inequitable distribution of costs and benefits. For example, dryland salinity can sometimes be addressed by reforesting degraded areas to increase transpiration rates and thus cause water tables to fall back to safer levels. In 
Table 1. Examples of some ecosystem services potentially supplied by forests and the types of forest restoration required to supply these services.

\begin{tabular}{|c|c|c|}
\hline Ecosystem services targeted & Type of forest required & Comments \\
\hline $\begin{array}{l}\text { Food, fuel, timber and nontimber forest } \\
\text { products for subsistence, trade, or cash income }\end{array}$ & $\begin{array}{l}\text { Forest contains species (native or exotic) able to } \\
\text { supply the desired product(s) }\end{array}$ & $\begin{array}{l}\text { A multispecies forest is likely to be able to } \\
\text { provide a wider variety of goods while also } \\
\text { having an enhanced degree of ecological and } \\
\text { economic resilience }\end{array}$ \\
\hline $\begin{array}{l}\text { Soil erosion control; water supply, regulation, } \\
\text { and filtration for agricultural and urban areas }\end{array}$ & $\begin{array}{l}\text { Structurally complex multispecies forests } \\
\text { including a dense understorey and deep-rooted } \\
\text { species }\end{array}$ & $\begin{array}{l}\text { Canopy should be open enough to sustain an } \\
\text { understorey layer; especially recommended for } \\
\text { steep/sloping lands, wetland forests, and riparian } \\
\text { areas }\end{array}$ \\
\hline $\begin{array}{l}\text { Carbon sequestration and long-term carbon } \\
\text { storage }\end{array}$ & $\begin{array}{l}\text { Uneven-aged, self-sustaining, multispecies } \\
\text { forests }\end{array}$ & $\begin{array}{l}\text { Should be able to regenerate after disturbances } \\
\text { such as wildfires, storms, or droughts }\end{array}$ \\
\hline Pollination & $\begin{array}{l}\text { Multispecies, containing the requisite fauna and } \\
\text { large populations of plant species }\end{array}$ & $\begin{array}{l}\text { Not all individuals of a particular species of } \\
\text { value will flower every year; therefore "large" } \\
\text { populations of each species may be needed }\end{array}$ \\
\hline $\begin{array}{l}\text { Habitat for flora and fauna, especially those } \\
\text { requiring conservation and restoration }\end{array}$ & $\begin{array}{l}\text { Multispecies and structurally complex using } \\
\text { native species with complementary flowering } \\
\text { and fruiting cycles that supply resources for } \\
\text { native populations }\end{array}$ & $\begin{array}{l}\text { Wild plants and animals differ in habitat } \\
\text { requirements; conflicts may arise with human } \\
\text { populations }\end{array}$ \\
\hline $\begin{array}{l}\text { Recreational, aesthetic, educational, social, } \\
\text { cultural, and spiritual benefits }\end{array}$ & Multispecies forests with scattered open areas & $\begin{array}{l}\text { Possible conflict between hunting, illegal logging } \\
\text { and drug production, and other forms of } \\
\text { recreation }\end{array}$ \\
\hline
\end{tabular}

this case, the best locations to do this may be in upper watershed areas of the affected landscapes where groundwater recharge is occurring, rather than in lower elevation areas where saline water is being discharged (Tongway and Ludwig 2011). The distance between the recharge and discharge areas may be significant, so that one landholder may bear the costs of reforestation while another reaps the benefits (Stirzaker et al. 2002, Harper et al. 2012)

In Figure 2, we explore these concepts in broad terms, fully cognizant that the availability and reliability of the various ecosystem services are often subject to fluctuations depending on ecosystem condition and climatic context. As an extreme example, in hyperarid coastal Peru, where one of us (OW) has been working for 15 years, ecosystems are exceedingly stressed and vulnerable to degradation. Significant pulses of rainfall, nutrients, and opportunities for renewal have come only in the form of an El Niño Southern Oscillation (ENSO) event, which has occurred once every 6-15 years during the latter half of the Holocene. The last event having taken place in 1997, the exhausted system is in a vulnerable state, and human-mediated drivers such as agroindustry and major irrigation schemes, along with a poorly understood outbreak of an insect- and fungus-mediated epidemic in the dominant Prosopis trees, are creating a worrying and unprecedented situation (O. Whaley, unpublished data), exacerbating vulnerability in a period of rapidly changing climate. The forest die-back and vulnerability of previously resilient and long-established vital components of the ecosystem, and also of rural livelihoods, force us to reconsider the approach to ecological restoration in coastal Peru. To address this and develop an adaptation strategy, the situation requires (1) scaling up ecosystem analysis with technology such as the long-range unmanned aerial vehicle and broad transect ground truthing; (2) extending historical perspective to ENSO trends during the late
Pleistocene and early Holocene; (3) targeting seed collection of resistant varieties or ecotypes of native plant species; and (4) identifying, with supporting baseline climate models, the key species for the adaptation processes most likely to rebuild both livelihood resources and system resilience over the emerging trajectories (O. Whaley, unpublished data). Here (see Fig. 2), for a long-degraded system, it is unlikely that the ecosystem can recover enough in the immediate future to provide services. However, with an appropriate restoration strategy, at least the system could be returned to provisioning and sustaining livelihoods, while providing a significant increase in other system services.

Fig. 2. Hypothetical levels of the five major types of ecosystem services provided by degraded production landscapes, rehabilitated production landscapes, and restored ecosystems.

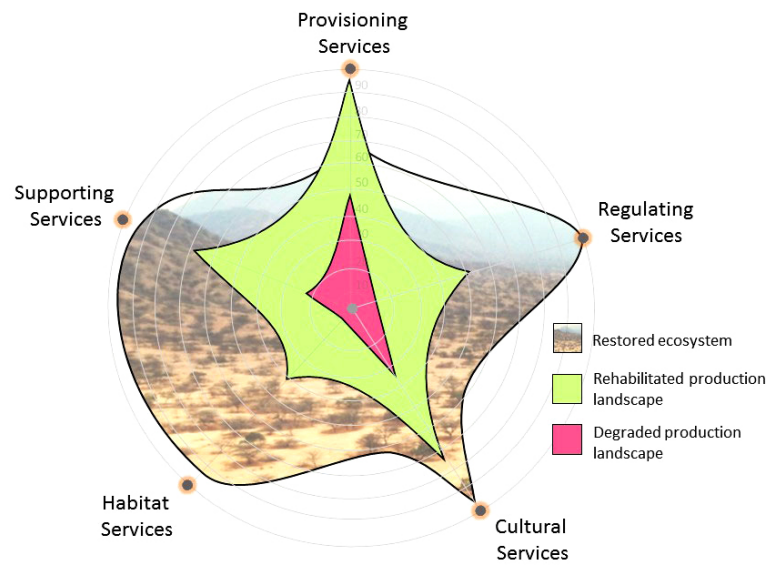


A recent study across four dryland areas in Latin America (Birch et al. 2010) examined the potential impact of forest restoration on the value of multiple ecosystem services. In all four study areas, there was a net gain in the overall delivery of ecosystem services, with carbon, tourism, timber, and nontimber forest products increasing in net value as a result of forest restoration. Only livestock production value (one of three provisioning services considered) decreased in all areas, representing an opportunity cost of forest restoration. This fits with the generalized depiction of hypothetical trade-offs portrayed in the radar diagram provided in Figure 2. In this conceptual representation, a restored ecosystem offers higher value service delivery in those areas relating to biodiversity (i.e., habitat, supporting, and regulating), prioritizing it toward a more stable and resilient ecosystem. In the rehabilitated production landscape, the provisioning-service value is higher but at the expense of biodiversity and sustainability, at least in the short- and mid-term time scales. In short, the desirability of different ecosystem services dictates the form of restoration or rehabilitation to be undertaken.

\section{MORE NEWS FROM THE FIELD}

In practice, the key challenge is to identify the type of intervention needed to reinstate particular ecological processes and functions, and thereby generate the ecosystem services required or desired in a given context or landscape. Although the principles of sustainable ecosystem management and restoration can help identify the processes and interventions required for biodiversity and ecosystem function and services at landscape scales, there is a need to do this in a way that accommodates local circumstances and priorities (Jørgensen and Nielsen 2012). In many cases that means creating incentives and negotiating trade-offs (Crossman and Bryan 2009, Bryan and Crossman 2013). Recent attempts to attribute values and account for nonmarket services, primarily those that deliver supporting, regulating, and cultural services, will help to refine the range of ecosystem management and restoration decision-making criteria (Ruhl and Chapin 2013).

In Cape Town, South Africa, a rapid ecosystem services assessment was used for prioritizing and targeting the restoration of degraded natural remnants of fynbos, which is the dominant vegetation type in the Cape Region. The methodology used in this expanding urban area involved a broad suite of services, linking them to spatial data on biophysical variables (e.g., water, vegetation, and wildlife), land and water use (e.g., organic farming, wasteland, and landfills), and the proximity of the nearest remnant to the delivery of these services (O'Farrell et al. 2012). Both along the coastlines and inland, natural vegetation generally provides the highest level of soil retention, preventing it from eroding and filling storm water systems and rivers with sediments. It also improves grazing potential, reduces unsightly land scarring produced by soil erosion, and protects critical infiltration areas within the city that play an important role in absorbing large volumes of rain water.

O'Farrell et al. (2012) show how changes to date, and potential future changes, in ecosystem services supply can be mapped and quantified as a percentage of the potential service produced in their study area. However, they do not show how conflicts in landuse priority among current users can be resolved and do not address the potential or any kind of roadmap for restoration. This kind of distance analysis is particularly useful in that it reinforces the need to consider ecosystem services and stakeholders at the landscape scale when making management and restoration decisions, particularly for those regulating and supporting services that are exclusively delivered in situ, e.g., flood mitigation and coastal protection. Initially conceived as a scoping tool, this type of rapid assessment could serve as a platform to orient or modify existing restoration efforts with applications that go beyond urban areas.

A similar approach was taken in a rural area of South Africa, in the context of the Grassland Programme, wherein five ecosystem services were mapped (below-ground carbon storage, surface water supply, water flow regulation, soil accumulation, and soil retention) and respective priority areas for individual services as well as the full suite of services were identified. A significant overlap between ecosystem services priority areas and the already identified biodiversity conservation priority areas demonstrated the possibility of integrating multiple objectives in management and restoration decision making (Egoh et al. 2011).

Figueroa and Aronson (2006) also addressed this issue with regard to various goods and services flowing from protected areas, such as national parks, to poor landholders living nearby. They considered these services in terms of economic costs and benefits to rural populations in developing countries, citing the case of the Bwindi Impenetrable National Park in Uganda. They specifically addressed restoration as part of a revamped planning process based on the concept of social-ecological systems and suggested taking steps to make protected areas hubs of rural economies so that benefits would far outweigh costs to neighbors.

Could the above approaches be taken for restoration and restoring natural capital programs? Recall that degraded areas are generally home to people who are among the world's poorest, most isolated from markets, and directly dependent on natural resources. Restoration policy must take on board this reality and recognize, through investment, that these communities and their activities are vital to the sustainable provision of ecosystem services. A very promising ten-year-old restoration program in the subtropical thicket of central South Africa has recently been summarized by Mills et al. (2015) with a strong emphasis on the quantification of ecosystem services at the landscape scale that are provided by thickets undergoing restoration. Thickets have been poorly recognized as providers of multiple ecosystem services, and of course as such, are especially vulnerable to degradation by communities and agroindustries alike.

In Latin America, the Regional Integrated Silvo-pastoral Ecosystem Management Project (Colombia, Ecuador, and Nicaragua) is one example where an ecosystem services index has been successfully utilized in a payment-for-ecosystem services scheme. Participants are paid for net increases in the index that aggregates values for biodiversity, provisioning services (e.g., food, water), and carbon sequestration (Pagiola et al. 2007). The rationale behind this Global Environmental Facility-sponsored project is that agricultural and livestock producers view many important services as externalities or public goods and thus do not have the proper incentives to protect and restore them.

Finally, it is worth comparing two examples of how multiple ecosystem services are driving large-scale restoration programs in highly populated areas of poor rural people in China and sub- 
Saharan Africa. In fact, both are restoration-of-natural-capital programs, in our understanding of that term. The first of these is a forest restoration and rehabilitation program known in China as the Grain-for-Green Program. In this case, agricultural land on slopes of greater than 25 degrees is being reforested to protect watersheds (Liu et al. 2008). The areas being restored are expected to cover 30 million hectares of former croplands. Although the primary objective of the program is to provide watershed protection, much of the initial restoration was done using a small number of commercial tree species simply because they were more readily available, which often resulted in low survival rates. Early results suggest there have been some improvements in watershed protection without a significant reduction in regional food production (Xu 2011, Deng et al. 2012). However, by using a wider variety of native species it may be possible to make the restoration process more effective and sustainable. Similar adjustments to restoration methodologies are called for in other large-scale restoration programs in China (Liu et al. 2008, Cao 2011).

The second large-scale program we refer to is the so-called Great Green Wall stretching across the entire Sahel, the semiarid, highly degraded, and densely populated belt on the southern fringe of the Sahara desert. As Sacandé and Berrahmouni (in press) show, cultural aspects are as important as technical and scientific aspects to make a large-scale project of this type survive and prosper. Combined with seed bank and biogeographical knowledge about niches of the tree species, the practitioners and scientists in the Great Green Wall are working to incorporate motivated local communities in selected portions of these highly degraded and frequently drought-stricken regions within a coordinated network of long-term projects aimed at kick-starting the restoration of natural capital at local scales, in the name of ecosystem services enhancement to local people. The approach taken combines the reintroduction of native trees and shrubs in a restoration framework with economic and ecological rehabilitation of traditional agroforestry systems via the use of nonnative trees in a simpler reforestation framework. Ultimately, the local communities must be convinced that there is a tangible benefit for them in terms of their livelihoods and well-being.

In many cases, it is difficult to implement restoration activities at a particular site to optimize livelihood benefits and, at the same time, generate short-term improvements in biodiversity and ecosystem health. However, it is possible to achieve a degree of both through incremental changes over time. Figure 3 presents an illustration of how this might work in practice using forest restoration as an example. If reforestation is carried out using traditional monoculture plantations of exotic species (arrow 1), this pathway generates financial benefits with only modest biodiversity gains. In contrast, when using restoration methods that maximize diversity (arrow 2), fewer direct financial benefits to landowners are generated in the short-term. Protecting and facilitating forest regrowth (arrow 3) generate improvements in both biodiversity and livelihoods, although the magnitude of the financial benefits depends on the population density of commercially or socially important species; these benefits can be enhanced by the enrichment of secondary forest with commercially attractive species (arrow 4).

Restoration-of-natural-capital programs in landscapes where poverty is prevalent necessitates pursuing both objectives simultaneously. In many cases, it may be necessary to give initial priority to forms of reforestation that increase tangible economic benefits, such as multispecies woodlots (arrow 5). In subsequent rotations, this balance might change over time (moving to arrow 6 and later to arrow 7) by using a greater variety of species to develop, for example, the habitat for species conservation and increasing the range of ecosystem services provision. Addressing problems at the landscape scale is critical, and there may be greater scope for achieving multiple objectives by using several of these options at different locations within the landscape mosaic (Lamb et al. 2005). Ultimately, the concept of ecosystem services can be of strategic value in efforts to collectively clarify long-term goals and achieve consensus and buy-in at the level of local communities, as well as with decision makers from various levels of government. In addition, another very high priority is monitoring and evaluating the ecosystem services that arise from assisted and spontaneous natural regeneration and active restoration (Chazdon 2008, 2014).

Fig. 3. The trade-offs that people may need to make between biodiversity maintenance and livelihood benefits. The relationship can change over time as social and economic circumstances change (modified from Lamb et al. 2005).

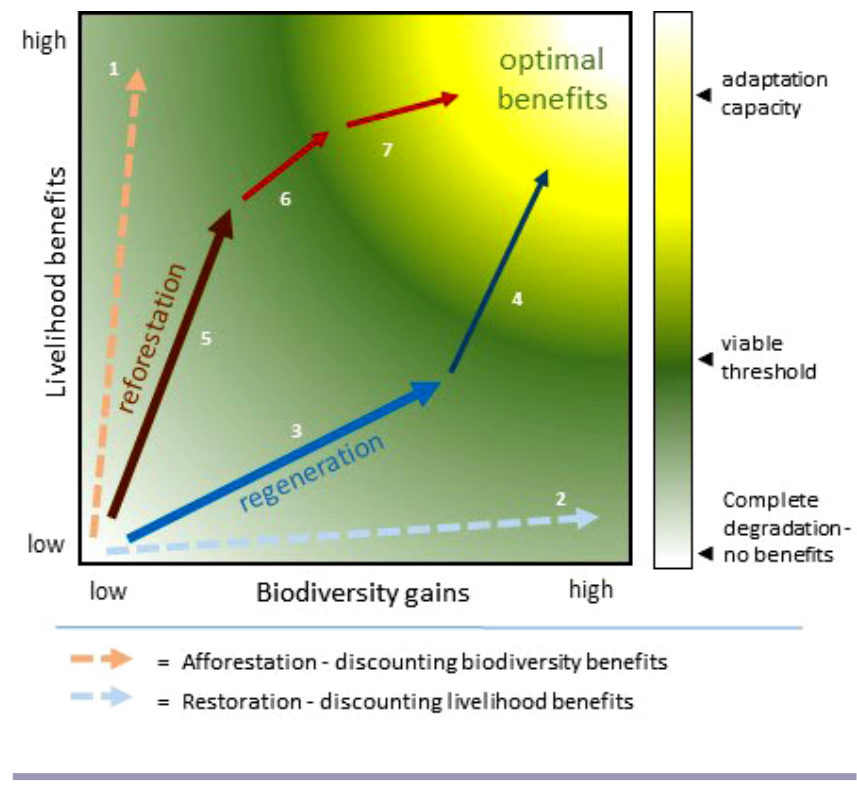

\section{CONCLUSIONS}

There is a strong relationship between ecological restoration and the ecosystem services concept, with the latter providing some guidance on how ecological restoration may be planned and implemented. However, as Mills et al. (2015) note, ecosystem restoration at the scale we now require may perhaps only be feasible long-term if the private sector gets involved, driven by the fact that restored ecosystems will be more productive and resilient than degraded ones. This is nowhere more critical than in the efforts to combat global climate change, because the landuse sector represents approximately $25 \%$ of total greenhouse gas emissions (Smith et al. 2014).

Reducing Emissions from Deforestation and Forest Degradation (REDD) is an international fund- or credit-based mechanism for reducing carbon emissions and protecting forest ecosystems. Now 
known as REDD+, it "has expanded beyond a sole focus on activities that affect carbon budgets to also include those that enhance ecosystem services and deliver other co-benefits to biodiversity and communities" (Alexander et al. 2011:683). Although the pressing need for large-scale ecological restoration and rehabilitation, assisted natural generation, and a fully functioning REDD+ mechanism is increasingly understood, moving forward in policy and financing at national and subnational levels may be slow. This is in part because of the failure to effectively demonstrate and communicate the value of the full suite of ecosystem services that result from restoration projects and programs (Alexander and McInnes 2012). This failure is linked to and aggravated by other factors such as (1) market failures whereby some ecosystem services are considered public goods; (2) perverse incentives for unsustainable land and water management practices; (3) inequitable spatial and temporal distribution of costs and benefits (i.e., it may take decades before some forms of restoration are able to generate anywhere near the full spectrum of ecosystem services targeted (Moreno-Mateos et al. 2012); and (4) lack of appropriate governance, institutions, and systems including tenure, gender, and resource rights.

Given the depth and breadth of global changes causing shifts and realignments in both human communities and ecosystems, and given the urgency to address the plight of huge portions of humanity in rural areas, restoring natural capital provides a promising and viable approach, with emphasis given by planners to deciding which ecosystem services are needed where, as well as when and for whom. The nature of the trade-offs required is likely to vary within and across landscapes, depending on which suite of ecosystem services is desired by which stakeholders in particular places and landscape units. Especially when it comes to large-scale restoration and restoring-natural-capital programs, prescribing an experimental approach that has been called intelligent tinkering (Murcia and Aronson 2014, and references therein) makes good sense. Economic activities and circumstances will also change while ecosystems develop in response to new management interventions. New policies and institutions will be needed to facilitate a pragmatic approach (Lamb 2014), and new sources of financing will have to be identified and mobilized, including those from the business community (http://www. naturalcapitaldeclaration.org/).

Responses to this article can be read online at: http://www.ecologyandsociety.org/issues/responses. $\mathrm{php} / 8288$

\section{Acknowledgments:}

We thank Thibaud Aronson, two anonymous reviewers, the coordinating editor, and the editor-in-chief for very helpful comments on a previous version.

\section{LITERATURE CITED}

Alexander, S., and R. McInnes. 2012. The benefits of wetland restoration. Ramsar Scientific and Technical Briefing Note No. 4. Ramsar Convention Secretariat, Gland, Switzerland.
Alexander, S., C. R. Nelson, J. Aronson, D. Lamb, A. Cliquet, K. L. Erwin, C. M. Finlayson, R. S. de Groot, J. A. Harris, E. S. Higgs, R. J. Hobbs, R. R. Robin Lewis, III, D. Martinez, and C. Murcia. 2011. Opportunities and challenges for ecological restoration within REDD+. Restoration Ecology 19(6):683-689. http://dx.doi.org/10.1111/j.1526-100x.2011.00822.x

Aronson, J., and S. Alexander. 2013. Ecosystem restoration is now a global priority: time to roll up our sleeves. Restoration Ecology 21(3):293-296. http://dx.doi.org/10.1111/rec.12011

Aronson, J., S. J. Milton, and J. N. Blignaut. 2007. Definitions and rationale. Pages 3-8 in J. Aronson, S. J. Milton, and J. Blignaut, editors. Restoring natural capital: science, business, and practice. Island Press, Washington, D.C., USA.

Birch, J. C., A. C. Newton, C. A. Aquino, E. Cantarello, C. Echeverría, T. Kitzberger, I. Schiappacasse, and N. T. Garavito. 2010. Cost-effectiveness of dryland forest restoration evaluated by spatial analysis of ecosystem services. Proceedings of the National Academy of Sciences of the United States of America 107(50):21925-21930. http://dx.doi.org/10.1073/pnas.1003369107

Bryan, B. A., and N. D. Crossman. 2013. Impact of multiple interacting financial incentives on land use change and the supply of ecosystem services. Ecosystem Services 4:60-72. http://dx.doi. org/10.1016/j.ecoser.2013.03.004

Bullock, J. M., J. Aronson, A. C. Newton, R. F. Pywell, and J. M. Rey-Benayas. 2011. Restoration of ecosystem services and biodiversity: conflicts and opportunities. Trends in Ecology \& Evolution 26(10):541-549. http://dx.doi.org/10.1016/j.tree.2011.06.011

Cao, S. 2011. Impact of China's large-scale ecological restoration program on the environment and society in arid and semiarid areas of China: achievements, problems, synthesis, and applications. Critical Reviews in Environmental Science and Technology 41(4):317-335. http://dx.doi.org/10.1080/10643380902800034

Chaves, R., G. Durigan, P. Brancalion, and J. Aronson 2015. On the need of legal frameworks for assessing restoration projects success: new perspectives from São Paulo state (Brazil). Restoration Ecology 23(6):754-759. http://dx.doi.org/10.1111/ rec. 12267

Chazdon, R. L. 2008. Beyond deforestation: restoring forests and ecosystem services on degraded lands. Science 320 (5882):1458-1460. http://dx.doi.org/10.1126/science.1155365

Chazdon, R. L. 2014. Second growth: the promise of tropical forest regeneration in an age of deforestation. University of Chicago Press, Chicago, Illinois, USA. http://dx.doi.org/10.7208/ chicago/9780226118109.001.0001

Clewell, A. F., and J. Aronson. 2013. Ecological restoration: principles, values, and structure of an emerging profession. Second edition. Island Press, Washington, D.C., USA. http://dx.doi. org/10.5822/978-1-59726-323-8

Convention on Biological Diversity (CBD). 2012. UNEP/CBD/ COP Decision XI/16. Ecosystem restoration. Convention on Biological Diversity, Hyderabad, India. [online] URL: $\underline{\text { http:// }}$ www.cbd.int/doc/decisions/cop-11/cop-11-dec-16-en.pdf 
Costanza, R., and H. E. Daly. 1992. Natural capital and sustainable development. Conservation Biology 6(1):37-46. http:// dx.doi.org/10.1046/j.1523-1739.1992.610037.x

Crossman, N. D., and B. A. Bryan. 2009. Identifying cost-effective hotspots for restoring natural capital and enhancing landscape multifunctionality. Ecological Economics 68(3):654-668. http:// dx.doi.org/10.1016/j.ecolecon.2008.05.003

de Groot, R., B. Fisher, M. Christie, J. Aronson, L. Braat, R. Haines-Young, J. Gowdy, E. Maltby, A. Neuville, and S. Polasky. 2010. Integrating the ecological and economic dimensions in biodiversity and ecosystem service valuation. Pages 9-40 in $\mathrm{K}$. Pushpam, editor. The economics of ecosystems and biodiversity: ecological and economic foundations. Earthscan, London, UK.

de Groot, R. S., J. Blignaut, S. van der Ploeg, J. Aronson, T. Elmqvist, and J. Farley. 2013. Benefits of investing in ecosystem restoration. Conservation Biology 27(6):1286-1293. http://dx.doi. org/10.1111/cobi.12158

Deng, L., Z. Shangguan, and R. Li. 2012. Effects of the grainfor-green program on soil erosion in China. International Journal of Sediment Research 27(1):120-127. http://dx.doi.org/10.1016/ s1001-6279(12)60021-3

Díaz, S., S. Demissew, C. Joly, W. M. Lonsdale, and A. Larigauderie. 2015. A Rosetta stone for nature's benefits to people. PLoS Biology 13(1):e1002040. http://dx.doi.org/10.1371/ journal.pbio. 1002040

Economics of Ecosystems and Biodiversity (TEEB). 2010. The economics of ecosystems and biodiversity: ecological and economic foundations. K. Pushpam, editor. Earthscan, London, UK.

Egoh, B. N., M. L. Paracchini, G. Zulian, J. P. Schägner, and G. Bidoglio. 2014. Exploring restoration options for habitats, species and ecosystem services in the European Union. Journal of Applied Ecology 51(4):899-908. http://dx.doi.org/10.1111/1365-2664.12251

Egoh, B. N., B. Reyers, M. Rouget, and D. M. Richardson. 2011. Identifying priority areas for ecosystem service management in South African grasslands. Journal of Environmental Management 92(6):1642-1650. http://dx.doi.org/10.1016/j.jenvman.2011.01.019

Falk, D. A., M. Palmer, and J. Zedler, editors. 2006. Foundations of restoration ecology. Island Press, Washington, D.C., USA.

Figueroa, E., and J. Aronson. 2006. New linkages for protected areas: making them worth conserving and restoring. Journal for Nature Conservation 14:225-232. http://dx.doi.org/10.1016/j. inc. 2006.04.007

Guerry, A. D., S. Polasky, J. Lubchenco, R. Chaplin-Kramer, G. C. Daily, R. Griffin, M. Ruckelshaus, I. J. Bateman, A. Duraiappah, T. Elmqvist, M. W. Feldman, C. Folke, J. Hoekstra, P. M. Kareiva, B. L. Keeler, S. Li, E. McKenzie, Z. Ouyang, B. Reyers, T. H. Ricketts, J. Rockström, H. Tallis, and B. Vira. 2015. Natural capital and ecosystem services informing decisions: from promise to practice. Proceedings of the National Academy of Sciences of the United States of America 112(24):7348-7355. http://dx.doi.org/10.1073/pnas. 1503751112

Harper, R. J., K. R. J. Smettem, P. V. Townsend, J. R. Bartle, and J. F. McGrath. 2012. Broad-scale restoration of landscape function with timber, carbon and water investment. Pages 275-292 in J. Stanturf, D. Lamb, and P. Madsen, editors. Forest landscape restoration. Springer, Dordrecht, Netherlands. http://dx.doi. org/10.1007/978-94-007-5326-6_14

Holl, K. D., E. E. Crone, and C. B. Schultz. 2003. Landscape restoration: moving from generalities to methodologies. BioScience 53(5):491-502. http://dx.doi.org/10.1641/0006-3568 (2003)053[0491:lrmfgt]2.0.co:2

Intergovernmental Platform on Biodiversity and Ecosystem Services (IPBES). 2013. Deliverable 3(b) ( $i$ ): Thematic assessment on land degradation and restoration. IPBES, Bonn, Germany. http://www.ipbes.net/work-programme/land-degradation-and-restoration

International Union for Conservation of Nature (IUCN). 2014. Forest and landscape restoration. IUCN, Gland, Switzerland.

Jørgensen, S. E., and S. N. Nielsen. 2012. Tool boxes for an integrated ecological and environmental management. Ecological Indicators 21:104-109. http://dx.doi.org/10.1016/j.ecolind.2011.09.005

Lamb, D. 2011. Regreening the bare hills: tropical forest restoration in the Asia-Pacific region. Springer, Dordrecht, Netherlands. http://dx.doi.org/10.1007/978-90-481-9870-2

Lamb, D. 2014. Large-scale forest restoration. EarthscanRoutledge, Abingdon, UK.

Lamb, D., P. D. Erskine, and J. A. Parrotta. 2005. Restoration of degraded tropical forest landscapes. Science 310(5754):1628-1632. http://dx.doi.org/10.1126/science. 1111773

Liu, J., S. Li, Z. Ouyang, C. Tam, and X. Chen. 2008. Ecological and socioeconomic effects of China's policies for ecosystem services. Proceedings of the National Academy of Sciences of the United States of America 105(28):9477-9482. http://dx.doi. org/10.1073/pnas.0706436105

Mace, G. M., K. Norris, and A. H. Fitter. 2012. Biodiversity and ecosystem services: a multilayered relationship. Trends in Ecology \& Evolution 27(1):19-26. http://dx.doi.org/10.1016/j.tree.2011.08.006

Meine, C., M. Soulé, and R. F. Noss. 2006. "A mission-driven discipline": the growth of conservation biology. Conservation Biology 20(3):631-651. http://dx.doi.org/10.1111/j.1523-1739.2006.00449. $\underline{x}$

Millennium Ecosystem Assessment (MA). 2005. Ecosystems and human well-being: biodiversity synthesis. Island Press, Washington, D.C., USA.

Mills, A. J., M. van der Vyver, I. J. Gordon, A. Patwardhan, C. Marais, J. Blignaut, A. Sigwela, and B. Kgope. 2015. Prescribing innovation within a large-scale restoration programme in degraded subtropical thicket in South Africa. Forests 6 (11):4328-4348. http://dx.doi.org/10.3390/f6114328

Moreno-Mateos, D., M. E. Power, F. A. Comín, and R. Yockteng. 2012. Structural and functional loss in restored wetland ecosystems. PLoS Biology 10(1):e1001247. http://dx.doi. org/10.1371/journal.pbio.1001247

Murcia, C., and J. Aronson. 2014. Intelligent tinkering in ecological restoration. Restoration Ecology 22(3):279-283. http:// dx.doi.org/10.1111/rec. 12100 
Naeem, S. 2002. Ecosystem consequences of biodiversity loss: the evolution of a paradigm. Ecology 83(6):1537-1552. http://dx.doi. org/10.1890/0012-9658(2002)083[1537:ecoblt]2.0.co;2

Neßhöver, C., J. Aronson, J. Blignaut, F. Eppink, A. Vakrou, H. Wittmer, and R. de Groot. 2011. Investing in ecological infrastructure. Pages 401-448 in P. Ten Brink, editor. The economics of ecosystems and biodiversity in national and international policy making. Earthscan, London, UK.

O’Farrell, P. J., P. M. L. Anderson, D. C. Le Maitre, and P. M. Holmes. 2012. Insights and opportunities offered by a rapid ecosystem service assessment in promoting a conservation agenda in an urban biodiversity hotspot. Ecology and Society 17(3):27. http://dx.doi.org/10.5751\%2FES-04886-170327

Pagiola, S., E. Ramírez, J. Gobbi, C. de Haan, M. Ibrahim, E. Murgueitio, and J. P. Ruíz. 2007. Paying for the environmental services of silvopastoral practices in Nicaragua. Ecological Economics 64(2):374-385. http://dx.doi.org/10.1016/j. ecolecon.2007.04.014

Palmer, M. A., and S. Filoso. 2009. Restoration of ecosystem services for environmental markets. Science 325(5940):575-576. http://dx.doi.org/10.1126/science.1172976

Rees, W. E. 1995. Cumulative environmental assessment and global change. Environmental Impact Assessment Review 15:295-309. http://dx.doi.org/10.1016/0195-9255(95)00029-E

Ruhl, J. B., and F. S. I. Chapin. 2013. Ecosystem services, ecosystem resilience, and resilience of ecosystem management policy. In C. R. Allen and A. S. Garmestani, editors. Resilience and law. Columbia University Press, New York, New York, USA.

Sacandé, M., and N. Berrahmouni. Community participation and ecological criteria for selecting species and restoring natural capital with native species in the Sahel. Restoration Ecology, in press. http://dx.doi.org/10.1111/rec.12337

Schröter, M., E. H. van der Zanden, A. P. E. van Oudenhoven, R. P. Remme, H. M. Serna-Chavez, R. S. de Groot, and P. Opdam. 2014. Ecosystem services as a contested concept: a synthesis of critique and counter-arguments. Conservation Letters 7 (6):514-523. http://dx.doi.org/10.1111/conl.12091

Smith P., M. Bustamante, H. Ahammad, H. Clark, H. Dong, E. A. Elsiddig, H. Haberl, R. Harper, J. House, M. Jafari, O. Masera, C. Mbow, N. H. Ravindranath, C. W. Rice, C. Robledo Abad, A. Romanovskaya, F. Sperling, and F. Tubiello. 2014. Agriculture, forestry and other land use (AFOLU). In O. Edenhofer, R. PichsMadruga, Y. Sokona, E. Farahani, S. Kadner, K. Seyboth, A. Adler, I. Baum, S. Brunner, P. Eickemeier, B. Kriemann, J. Savolainen, S. Schlömer, C. von Stechow, T. Zwickel and J. C. Minx, editors. Climate change 2014: mitigation of climate change. Working Group III contribution to the Fifth Assessment Report of the Intergovernmental Panel on Climate Change. Cambridge University Press, Cambridge, UK.

Society for Ecological Restoration (SER). 2004. The SER primer on ecological restoration. Society for Ecological Restoration International, Washington, D.C., USA.

Stirzaker, R., R. Vertessy, and A. Sarre. 2002. Trees, water and salt: an Australian guide to using trees for healthy catchments and productive farms. Rural Industry Research and Development Corporation, Canberra, Australia.

Suding, K. N. 2011. Toward an era of restoration in ecology: successes, failures, and opportunities ahead. Annual Review of Ecology, Evolution, and Systematics 42:465-487. http://dx.doi. org/10.1146/annurev-ecolsys-102710-145115

Tongway, D. J., and J. A. Ludwig. 2011. Restoring damaged rangelands. Pages 45-61 in Restoring disturbed landscapes. Island Press, Washington, D.C., USA. http://dx.doi.org/10.5822/978-1$\underline{-61091-007-1 \quad 5}$

Whaley, O. Q., D. G. Beresford-Jones, W. Milliken, A. Orellana, A. Smyk, and J. Leguía. 2011. An ecosystem approach to restoration and sustainable management of dry forest in southern Peru. Kew Bulletin 65(4):613-641. http://dx.doi.org/10.1007/ s12225-010-9235-y

World Bank. 2010. The changing wealth of nations: measuring sustainable development in the new millennium. World Bank, Washington, D.C., USA. http://dx.doi.org/10.1596/978-0-8213-8488-6

Worster, D. 1977. Nature's economy: a history of ecological ideas. Cambridge University Press, Cambridge, UK.

$\mathrm{Xu}, \mathrm{J}$. 2011. China's new forests aren't as green as they seem. Nature 477(7365):371. http://dx.doi.org/10.1038/477371a 